\title{
Epistimology of Urf in the Usulul Fiqh
}

\author{
Mochamad Su'eb \\ Universitas Sunan Giri Surabaya \\ msueb@yahoo.com
}

\begin{abstract}
Science Fiqh is one of the sciences that need to be known by all Muslims because it involves Islamic laws. Overall, this knowledge is not easy to understand. Therefore, they need an introduction to this knowledge that is very important because it can direct understanding towards Fiqh true. In addition, as a scientific discipline, Fiqh will continue and must develop. Even so, the changes in history show dynamics. Sometimes it changes very rapidly. Sometimes it also looks slow. In fact, it is not uncommon to seem static. In fact, the demand for its development is a logical consequence of the burden and demands of changing society and Muslims themselves. In this paper, we will discuss something related to the social life of society, that is habit or in the language of Fiqh "Urf".
\end{abstract}

Keyword : Epistimology, Urf, Usulul Fiqh

\section{INTRODUCTION}

One branch of science in Islamic intellectual property is usul fiqh. As a science that discusses the foundations underlying the birth of fiqh law, the urgency of ushul fiqh is increasing, especially as a handle in answering various legal issues nowadays. Jurul fiqh is more a certain rules that are used as a handle or rules for the birth process of a law. Because of this kind of working area, it applies globally to both legal and other issues. As we know, giving birth to an answer to a legal problem is not easy, especially if the law is related to fiqh issues. If there is a recent legal problem, it is impossible if we can immediately issue the answer without the thought process first. There are a set of rules that must be met in order to give birth to that answer.

\section{RESULT AND DISCUSSION}

\section{Definition of ' $U r f$}

In terms of etymology al-'Urf comes from words consisting of the letters 'ain, ra ' and $f a^{\prime}$ which means to know. From this word comes the word ma'rifah (known), ta'rif (definition), the word ma'ruf (known as goodness), and the word 'Urf (good habit).

As for the terminology. The word 'Urf meaning:

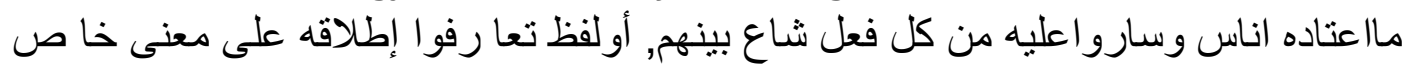
seuatu the human habits, and they followed him in the form of any act which is popular among them, or a word that they are familiar with in a certain sense, not in 
an etymological sense, and when they hear that word, they do not understand it in another sense (Dahlan, 2010).

In fuqaha 'Urf terms are habits. From this understanding we know that 'Urf in a case cannot be realized unless' urf must apply or frequently applies to the case, so that people who have' urf always pay attention and adjust to it. So the element of formation of 'Urf is mutual habituation, and this only exists in a continuous or frequent state and if not, it is called corporate behavior.

An example is the custom of Indonesian society in marriage is that the family of the prospective bridegroom comes to the prospective bride's parents' parents to ask for her hand (Hanafi, 1995). In addition, in customary acts, such as the habits of humanity in buying and selling by exchanging directly, without any form of contract. And also their habit of not saying the word "meat" as "fish" (Khallaf, 2003).

\section{Types of 'Urf}

The Ulema of Usul Fiqh divided' Urf into three types:

1. In terms of its object:

a. Al-'Urf al-Lafzhi (habits involving expressions).

It is the community's habit to use certain pronunciation / expressions in expressing something, so that the meaning of that expression is understood and crossed the minds of the people. For example the phrase "meat" which means beef; whereas the words "meat" include all the meat that is there. When someone goes to a meat seller, while the meat seller has a variety of meat, then the buyer says "I bought $1 \mathrm{~kg}$ of meat" the merchant immediately takes the beef, because the local community has specialized in using the word meat on beef.

b. Al-'Urf al-'amali (habits in the form of deeds).

Is a community habit that is related to ordinary actions or civil mu'amalah. What is meant by "ordinary deeds" are people's habits in matters of their lives that are not related to the interests of others, such as the habit of working days off on certain days of the week, people's habits of eating special food or drinking certain drinks and people's habits in using certain clothes on special occasions.

2. In terms of scope:

a. Al-'Urf al-'am (general habits).

It is a custom that is widely applicable in all communities and throughout the region. For example in the sale and purchase of a car, all tools needed to repair a car such as keys, pliers, jacks and spare tires are included in the sale price, without their own contract and additional costs. Another example is the prevailing custom that the weight of luggage for each passenger of an aircraft is twenty kilograms. 
b. Al-'Urf al-khash (special habits).

Is a custom that applies in certain regions and communities. For example among traders if there are certain defects in the goods purchased can be returned and for other defects in the goods, consumers cannot return the goods. Or also the custom regarding determining the warranty period for certain items.

3. In terms of validity from the perspective of syara ':

a. Al-'Urf al-Shahih (a habit that is considered valid)

Is a habit that applies in the midst of society that is not contrary to the text (verse or hadith) does not eliminate their kemaslahtan, and also does not bring harm to they. For example, during an engagement a man gives a gift to a woman and this gift is not considered a dowry.

b. Al-'Urf al-fasid (habits that are considered broken).

Is a habit that is contrary to the arguments of shara 'and the basic rules that exist in shara'. For example, the prevailing habits among traders in allowing usury, such as borrowing money between fellow traders. Borrowed money of ten million rupiahs within one month, must be paid as much as eleven million rupiahs if due, with an interest calculation of $10 \%$. In terms of the benefits achieved by the borrower, an additional debt of $10 \%$ is not enacting, because the benefits gained from the ten million rupiah may exceed the interest of $10 \%$. However, this practice is not a habit that is helpful to help in the view of syara', because the exchange of similar goods, according to syara' should not be exaggerated (Besri, 2016).

\section{Position of 'Urf as the Source of Law}

In social life in human societies which do not have laws (law-huum), it is' urf (habit) which becomes the Law governing them. So since ancient times' urf has a function as a law in human life.

Until now, 'Urf is considered as one of the sources of the law, in which many elements are taken from the applicable laws, then issued in the form of articles in the law.

Islamic Sharia came later recognized many acts of action and rights that were equally known by the Shari'ah of Islam and earlier Arab societies, while repairing and abolishing many other habits. In addition, Islamic Shari'ah also brings new laws that govern all aspects of human relations with each other in social life, on the basis of the need and guidance for the best possible solution, because the Shari'ahs of God with the rules the civil code (in terms of worldliness) is intended to regulate human interests and rights. Therefore, existing habits can be 
recognized as long as they are able to realize their goals and in accordance with their general basics.

In Shari'a arguments used as a basis to consider 'Urf (custom) as the source of law is the word of Allah SWT.

Although the words 'Urf here are actually interpreted according to the meaning of language, which is a matter that is commonly known and considered good, but can also be used to strengthen' urf according to the meaning of the term, because of what is commonly known by many people in the actions and relationships with each others include things that are considered good by them and known by their minds (Hanafi, 1995).

\section{'Urf as the Proof of Shara'}

'Urf according to the investigation is not a proposition of shara' in itself. In general, urf is intended to maintain the benefit of the people and support the formation of law and interpretation of several texts. But this does not mean that the urf has no legal basis as one of the legitimate sources of Islamic shari'ah. Regarding the blasphemy of urf in the opinion of the ulama of ushul Fiqh , including:

1. Hanafiyah and Malikiyah groups argue that urf is the object of establishing Islamic law. Their reason is based on the word of God in Sura al A'rof verse 199:

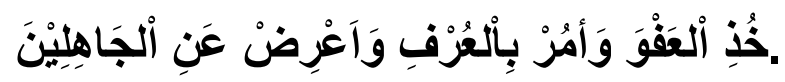

"Be forgiving, and tell people to do what is sorry and turn away from fools."

This verse means that urf is a human habit and what they often do (good). This verse, bersighat 'am means that Allah ordered His Prophet to do a good thing, because it is a command, then the urf is considered by the Shariah' as the legal proposition.

So from the statement above, it can be said that something that is commonplace by humans in the world for the benefit of their lives, then it is considered true by Islamic sharia even though there is no proof that states it either in the Qur'an or the Sunnah.

Besides based on the Qur'anic argument, Hanafiyah and Malikiyah scholars alsoProphet's hadith:

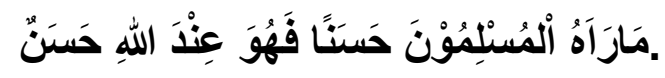

"Something that is considered good by Muslims, including a good thing according to God".

This hadith means that what is considered good for Muslims means it is good in the sight of Allah, which includes a good urf. Which based on these postulates, a good urf is a good thing before God.

2. Syafi'iyah and Hanbaliyah groups, both of them do not consider urf to be a hujjah or the proposition of sharia law. The Imam Shafi'i group does not 
recognize the existence of istihsan, they really refuse to use it in istinbath law and do not use it as an argument.[6]So with that, automatically the Shafi'ites also refuse to use urf as a source of Islamic law. His rejection was reflected in his words as follows:

"Anyone who uses istihsan then in fact he has made the law".

Even in his 'Minutes', he stated emphatically as follows, which means:

"No one has the right but the Messenger of Allah to stipulate a law without a reason (argument) and no one has the right to determine based on what is considered good (istihsan). In fact, establishing the law in istihsan is making new provisions that do not adhere to the provisions outlined earlier ".

In connection with his rejection of this istihsan, he put forward several arguments (arguments) as the basis for his rejection, as reflected in his books al-Risalah and al-Umm. He noted the arguments of al-Quran and hadith, among them:

1. Surah Al-Maidah (5): 3, which reads:

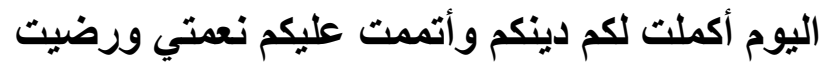

"Today I have perfected for you your religion, and have given you my favor, and has made Kuridhai Islam a religion for you."

2. Surah al-Nahl (16): 89 which reads:

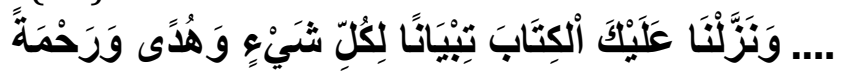

"And We send down to you al-Kitab (al-Qur'an) to explain everything and instructions and mercy".

Based on the arguments, the Imam Shafi'i rejects the source of the law from the urf, because he considers that urf is the determination of a law that is not based on a predetermined proposition namely; Al Qur'an, Hadith, Ijma 'and Qiyas (Hadits, 2012).

\section{'Urf must apply continuously or mostly apply}

What is meant by' continuous urf 'is that' urf is valid for all events without exception, the sedan meant by most ' $U r f$ ' is that 'the urf applies in most events. Which is the most valid measure according to the count-statistics. If something is the same strength as being accustomed to not being accustomed, then the case is called 'Urf-mustarak (' double urf). 'This kind of urf cannot be used as a basis and argument in determining rights and obligations because if the actions of many people at one time can be considered as an argument, then the legacy at other times is considered as opposing the proposition.

'Urf which is a source of law for an action must be present at the time the action is taken 
For' the urf arising from an act cannot be held, and this is to maintain the stability of the provisions of a law. For example, if the words "Sabilillah" in the zakat treasure according to ' $U r f$ at one time interpreted all the requirements of jihad for religion, or all paths of goodness absolutely, according to differences of opinion of the scholars in this matter, or the words "Ibnus-Sabil "Means people who run out of supplies on their way. Then the familiarized understanding changes, so that Sabilillah is interpreted as a adopted child who has no family, then the legal texts remain refuted to the understanding of 'first urf, which is valid at the time of the passage, because that understanding is what Syara wants', meanwhile the notions that come after the passage are not considered. Hence Ibn Nujaim say the following:

العرف الذى تحمل عليه الالفاظ انما هو المقا

" 'Urf on which the word is' urf that accompany and precede, not' urf that came later. Therefore the jurists say: "There is no consideration for the "Urf that comes later".

\section{There is no affirmation (nas) that is opposite to 'Urf.}

Legal determination based on 'Urf in this case is included in the determination based on conclusions (according to the implied). However, if the determination is contested by an affirmation, then delete the stipulation. Therefore something lending is limited by the affirmation of the person lending, both in terms of time or place or amount, even though the assertion is contrary to what is used. So if someone borrows a cargo vehicle from someone else, then he is considered to have been permitted to charge him according to his usual size. However, if the owner explicitly sets his own boundaries, even if contrary to custom, the borrower must not exceed these predetermined limits.

The use of 'Urf will not result in the exclusion of definite passages from the Shari'ah, because the texts of Shara' must take precedence over 'Urf. If the Syara 'text can be combined with' urf, then 'Urf can still be used(Hanafi, 1995).

\section{CONCLUSION}

'Urf can be said as a word and deed which involves habits that are often done. Various kinds of 'Urf, namely in terms of its objects (Al-'Urf al-Lafzhi and Al-'Urfal'amali), in terms of scope (Al-'Urf al-'am and Al-'Urf al-khash), in terms of its validity from the perspective of syara '(Al-'Urf al-Shahih and Al-'Urf al-fasid).

'Urf is considered as one of the sources of the law, in which many elements are taken from the applicable laws, then issued in the form of articles in the law. Terms' Urf as a source of Islamic law that is, 'Urf must apply continuously or most of it applies,' urf which is a legal source for an action must be present at the time of the action, there is no affirmation (nas) that is contrary to 'Urf, usage' urf will not result in the exclusion of definite passages from Shari'ah. 


\section{REFERENCES}

Dahlan , Abd.Rahman. 2010. Ushul Fiqh, Jakarta, Sinar Grafika Offset

Hanafi , Ahmad. 1995. Pengantar dan Sejarah Hukum Islam. Jakarta, PT Bulan Bintang

Haroen, Nasrun. 1996. UshulFiqih/NasrunHaroen, Jakarta logos.

Jumantoro, Totok. 2005. Kamus Ilmu Ushul Fiqh. Jakarta. Amzah.

Khallaf, Abdul Wahhab . 2003. Ilmu Ushul Fikih Kaidah Hukum Islam. Jakarta, Pustaka Amani

Nazar Bakry, Fiqih dan Ushul Fiqih , 1996, Edisi. 1, Cet. 3, Jakarta. PT .Raja Grafindo Persada.

Syarifudin, Amir. 2008. Ushul Fiqh. Jakarta. KENCANA PRENADA MEDIA GROUP Syarifuddin Amir, 2011. Ushul Fiqh Jilid 1, Jakarta ,Kencana.

Syafe'i Rahmat.,Ilmu Ushul Fiqih , 2010,Cet. IV, Bandung, Pustaka Setia. 